\title{
Correlations of self-esteem with academic competencies: Gender variations
}

\author{
Mustapha AKOUL ${ }^{1}$, Saïd LOTFI ${ }^{2}$, Mohamed RADID ${ }^{3}$ \\ ${ }^{1}$ Normal Superior School (ENS); Observatory of Research in Didactics and University Pedagogy (ORDIPU), Faculty of \\ Science of Ben M'sik, Hassan II University of Casablanca, BP 50069, Ghandi, Morocco. akoulmustapha@ gmail.com \\ ${ }^{2}$ Researcher in Multidisciplinary Loboratory in Educations Sciences and Training Ingeneering. Assessment in Physical \\ Activity and Sport (REAPS), Normal Superior School (ENS), Hassan II University of Casablanca, BP 50069, Ghandi, \\ Morocco. lotfisaid@gmail.com \\ ${ }^{3}$ Researcher in the laboratory of chemistry of materials; Faculty of Science of Ben M'sik; Hassan II Casablanca University; \\ Morocco. m.radid@gmail.com
}

\begin{abstract}
The goal of this studyto assess, with validated instruments, the corollary links between students' academic results and the nature of their perceptions of their skills and self-esteem.

For accomplish this study, we have tested it on 255 student volunteers with an average age of 21 years (91 female students and 164 male students). We opted with two types of surveys: A questionnaire(SEQ) developed by Duclos. B., which measures self-esteem in five domains. Then a questionnaire on the perception of competence on three Domains of training (oral skills, written skills and physical practice skills). The Pearson correlation coefficient (r) is used to assess the intensity of the relationship between parameters. The data were processed with SPSS (26). The significance level is set to $\mathrm{p}<0.05$.
\end{abstract}

These variables combined in the synthesis of the results, confirm the initial hypothesis, that there is a correlation but only between a few domains of selfesteem, sense of competence and academic results obtained.

Indeed, students in this branch of education have a negative perception of their "academic" and "physical" self-esteem when their academic performance is modest or low.

On the other hand, the domains of family, social and overall self-esteem are not influenced despite modest academic achievement. The result is that even though students display a low sense of competence in the face of modest results during training, their self-esteem in the "family and social" domains stays stable with good scores.

Key words:Academic results, Corollary links, Gender, Perception of competence, Self-esteem.

\section{INTRODUCTION}

In psychology, self-esteem is a concept largely used and analysed in the scientific literature of Bariaud. F (2006), which does not facilitate its clear use. It is often studied and strongly mobilized during a transition between studies and work, according to a study by Cohen-Scali. \& V. Zein, R.Vignoli, E. Lallemand. N. (2019). Still, (Delignières, 2007) and Zedda, M., Thibodeau, S., and Lefebvre, S. (2018) through two studies separated in the time demonstrate that there are causal hypotheses to explain the selfesteem and solar results of young college students. Thus, the results show positive relationships between academic performance and three of the nine dimensions of self-esteem selected.Therefore, when we approach the subject of self-esteem, we find ourselves with a multitude of concepts that are used more or less synonymously. Self-esteem can therefore be explored from different angles and under multiple dimensions, Hepper, E.G., Gramzow, R.H., \&Sedikides, C. (2010).

Barbot. B, Safont-Mottay. C \&Oubrayrie-Roussel. N. (2019) put two types of theoretical models forward in this direction:uni-dimensional and multi-dimensional.

The unidimensional models consider self-esteem as a global entity, covering the whole concept of self: it is the general appreciation that an individual has of himself. The pioneers of this model include Coopersmith, (1967); Piers \& Harris (1964); Rosenberg (1979) cited by Fiassa. D \& NaderGrosbois. N. (2010).

Additionally, and taking into account the fact that individuals make different self-assessments in different domains of life. Harter. S. (1985) considers a multidimensional model more appropriate and constructs his instruments accordingly. They will focus on different domains of the concept of self: physical, relational, social, etc. Self-esteem is conceived in this model as a sectoral entity allowing the individual to make separate assessments of the different domains of his or her person. The notion of self-esteem is therefore one of the most ambiguous in psychology, the lack of a true empirical consensus leads to examining self-esteem according to different phenomena and areas of life.

Self-esteem/concept of self-scales vary considerably in their structure and content, raising questions about which scales are the most valid. In addition, a qualitative survey found that children value areas and content not found in these scales. Guerin, S. \&Tatlow- 
Golden, M. (2018) attribute this to the fact those scales are generally designed by adults, with little or no reference to children's representations.

Since 2002, in his work on the sense of self-efficacy, Bandura has argued that the sense of self-efficacy refers to individuals' beliefs about their ability to achieve particular performances. It helps to determine activity and environmental choices, the subject's investment in the pursuit of goals, the persistence of effort, and the emotional reactions he or she experiences when encountering obstacles. Sense of self-efficacy theory is used in many areas such as education, work, health, sport and even in collective actions that are marked by the belief shared by citizens in their ability to bring about change through Rondier collective action, Harter, S. (1993).

As a result, self-esteem and the feeling of self-efficacy represent two distinct theoretical constructs that are not systematically linked. Self-esteem can come from self-assessments based on personal competence, but also on the possession of personal characteristics invested with positive or negative values depending on the culture (social status, profession, etc.).

In primary education, and distinctly in secondary education, students who have good self-esteem, as compared to students who consider themselves modest, persevere more in their school work when they encounter difficulties, and use more effectively the skills and strategies they have developed to overcome their difficulties, Virat. M. (2014).

On the opposite, studies on this theme are rare in the initial training of physical education teachers. However, we have persuaded ourselves with RouxPerez. T. (2006), those novices in training are in line with the standards and requirements of training. They represent professional practices and engage in action according to the degree of recognition and the resulting sense of mastery of the situation, and this may lead to a partial reorganization of their perceptions during the next stages of training.

Observation shows that in initial teacher training, prior knowledge of the target does not have the place it deserves as a pedagogical device. Careful analysis of the simple didactic practices in use in training schools quite easily reveals the lack of psychological concepts contributing to this end. Aebli. H. (2019).

It is in this sense of verification and understanding of the population to be trained, that we are conducting this study in a university environment and precisely in the initial training of physical education teachers. The first objective is to measure the correlational links between students' academic results, the nature of their perceptions of their own skills and the level of their self-esteem with respect to the demands of training. For this will lead them towards a better optimization of the constraints and efforts they will face.

The purpose of this study is to identify the relationship the relationship between students' academic results, university competencies; and the level of their selfesteem. This work is part of a pilot project to accompagnement students during this professional training leading to students and trainers qualification.
We stipulate hypothetically that the results obtained by the students during the different stages of the training affect the levels of confidence and self-esteem and may condition all of their futures, their adaptations and finally the attainment of the desired academic and personal success. This is a statement also shared by Famose. J-P and Bertsch. J, (2009)in a secondaryschoolenvironment.

\section{METHODS}

\subsection{Population of studySubjects}

The profiles of the students who made up the sample for this study are heterogeneous in their physical profiles, as in the types of previous training followed. There were 255 student volunteers with an average age of 21 years (91 female students and 164 male students). They were pursuing training at the EcoleNormaleSupérieure CasablancaHassan II University.

\subsection{Measuring instruments}

2.2.1 The questionnaire (SEQ) of Duclos\& al. (2002) self-esteem scale, composed of 30 items divided into 5 dimensions (family self, social self, school self, physical self, global self).

2.2.2. Self Esteem Scale: The test measures the scores of Self Eesteem on five domains, dvelopped by Duclos et al (2002).

It consists of 30 items divided into 5 dimensions; (familial (six items), social (six items), school (six items), physical (six items), and global (six items).

The dimensions of self-esteem Scale are rated on a 4-point intensity scale: almost Never [ 1 point], sometimes [2points], often [3 points], usually [4 points]. The higher scores indicate greater self-esteem. The global score of self-esteem contained four levels: low self-esteem, somewhat good self-esteem, Very good self-esteem. Psychometric properties of the test [reliability and validity]: The questionnaire of selfassessment builds previously, present the following metric qualities: the correlation inter-items amounts to .32 , the internal consistency has of Cronbach: .80

\subsubsection{Competenciesperception Questionnaire}

This instrument is used to assess the variables related to the perception of competence, mobilized during university training. The evaluation is performed on a Likert scale on 4-levels: I am drowned in big gaps (1 pt), I feel the difficulties that accumulate (2pt), I find the requirements affordable (3pt), and I am in Perfect control of the situation (4pt). The score of each subject is the sum of the points obtained in each item. Three areas was assessed:

Practical skills, 7 items are assessed,Recuperating between training sessions; Leading a group on the field; Respecting the time available to engage in 
practice, Running in endurance, Supporting strength exercises, Being accepted by others in the game, Progressing in learning techniques; Following the rhythm of the practice sessions.

Oral competencies, 7 items are assessedExpressing yourself orally in a constructed manner, Speaking in front of the audience, Communicating your ideas to the teacher, Questioning the teacher, Listening and retaining oral exchanges, Retaining lectures.

Writing competencies, 8items are assessed Take notes, Use the draft, Analyze a question, Understand the expected work, Respect the instructions, Argue an answer, Elaborate a synthesis, Organize the research documents.

Subjects respond on 4-levels: I am drowned in big gaps (1 pt), I feel the difficulties that accumulate, I find the requirements affordable, and I am in Perfect control of the situation (4 pts) to the three types of training requirements. The score of each subject is the sum of the points obtained in each item.

The academic outcomes. We noted the school averages of seven teaching modules of first semester for the academic year 2018-2019, received from Schooling services. Each module isnoted on 20 pts.

\subsection{Design study}

Just at the beginning of the second half of the year in February. We distributed the first questionnaire The Duclos\& al. (2002) Self-Esteem Scale to students in a single session after linguistic explanation and clarification (translation of some terms into Arabic).

The questionnaire (analyzing variables related to the perception of one's competence) was tested for "content validation" on 30 cases of the promotion (LEEPS) 2017-2018 within the framework of a pilot project of student accompaniment and support. Then in a second phase. It was explained, distributed to the entire student sample through SurveyMonkey an online survey tool.

\subsection{Data analysis}

We used the Bravais-Pearson linear correlation coefficient (r) to analyze the relationships between the variables and the nonparametric Mann Withney test to compare means. The significance level is set at $<0.05$. To compare the variation in self-esteem scores according, we used the Mann Whitney test, which is a nonparametric test, to compare the means of two independent groups on the same variable; the readjustment of the calculations for all pairwise comparisons is done using the Bonferroni correction.

\section{RESULTS}

\subsection{Self-esteem levels and academic achievements correlation and gender.}

Table 1: Variation in levels of self-esteem, academic achievement and gender

\begin{tabular}{|c|c|c|c|c|}
\hline Parameters & Female & Male & Total & Test comparison \\
\hline $\begin{array}{l}\text { Academic } \\
\text { achievements }\end{array}$ & mean $\pm s d$ & mean $\pm s d$ & mean $\pm s d$ & pvalue Student test \\
\hline $\begin{array}{l}\text { Overall score (7 } \\
\text { modules) }\end{array}$ & $13.43 \pm 1.19$ & $12.90 \pm .88$ & $13.06 \pm 1.01$ & .025 \\
\hline $\begin{array}{l}\text { Note of the theoretical } \\
\text { modules }\end{array}$ & $12.39 \pm 1.89$ & $11.69 \pm 1.49$ & $11.90 \pm 1.64$ & .044 \\
\hline $\begin{array}{l}\text { Note of the practical } \\
\text { modules }\end{array}$ & $17.30 \pm 1.37$ & $16.73 \pm 1.17$ & $16.90 \pm 1.25$ & .039 \\
\hline $\begin{array}{l}\text { Self-evaluation of the } \\
\text { modules }\end{array}$ & $9.15 \pm 2.14$ & $8.40 \pm 1.92$ & $8.63 \pm 2.01$ & $.03 * *$ \\
\hline Self estem levels & $\%(n)$ & $\%(n)$ & $\%(n)$ & p value Khi2 test \\
\hline Physique self esteem & $36.67 \pm 8.89$ & $32.73 \pm 6.10$ & $34.71 \pm 7.03$ & .09 \\
\hline Familial self esteem & $44.19 \pm 6.95$ & $42.55 \pm 6.93$ & $43.06 \pm 6.94$ & ns \\
\hline Social self esteem & $34.22 \pm 9.48$ & $35.23 \pm 7.88$ & $34.92 \pm 8.37$ & .01 \\
\hline Scolaire self esteem & $31.30 \pm 8.47$ & $26.50 \pm 9.15$ & $28.37 \pm 8.99$ & .006 \\
\hline Global self esteem & $78.111 \pm 4.60$ & $70.301 \pm 2.70$ & $72.721 \pm 3.72$ & $.03 * *$ \\
\hline Low selffesteem & $3.7 \%(15)$ & $6.7 \%(47)$ & $5.7 \%(62)$ & ns \\
\hline Fairly good self-esteem & $66.7 \%(29)$ & $81.7 \%(79)$ & $77.0 \%(108)$ & $.05^{*}$ \\
\hline Very high self-esteem & $29.6 \%(47)$ & $11.7 \%(38)$ & 17.2785 & .013 \\
\hline Total & $35.69 \%(91)$ & $64.31 \%(164)$ & $100 \%(255)$ & ns \\
\hline
\end{tabular}

Variations in self-esteem and academic scores based on gender and their correlation are presented in Tables 1 and 2 , respectivelyabove.

Indeed, the statistics below from the training modules for this first timeframe show that the female gender has a relatively better score than the male gender. The adaptations of girls seem to be better marked than those of boys in theory as well as in practice. On the other hand, they show equal persisting scores in family self-esteem. What also marked these results is the disparity between the two genders in school (university) self-esteem. Girls once again show a superiority of the score, that is to $31.30 \pm 8.47$, while boys show only $26.50 \pm 9.15$ (006 p value Khi2 test) Table 1. On the other hand, the female genre had recorded "high self-esteem" a significant score compared to the male gender. (Table 1)

As a result, gender impacts on achievement scores by putting girls in a higher position than boys during this first semester of training. There is also a strong correlation between gender and the perception of overall self-esteem among females compared to males (Table 1). 


\subsection{Correlation between the academic self-esteem of genders and the evaluations obtained during training.}

Table 2. : Correlation matrix

betweenacademicachievementsand selfesteemdomains $(\mathrm{n}=255)$

\begin{tabular}{|c|c|c|c|c|c|}
\hline Parameters & & $\begin{array}{c}\text { Self- } \\
\text { evaluation }\end{array}$ & $\begin{array}{l}\text { Scores of the theory } \\
\text { modules }\end{array}$ & $\begin{array}{l}\text { Practical module } \\
\text { notes }\end{array}$ & $\begin{array}{l}\text { Global } \\
\text { score }\end{array}$ \\
\hline \multirow{2}{*}{$\begin{array}{l}\text { Physical } \\
\text { esteem }\end{array}$} & r & -12 & $.30 \%$ & .67 & $.43^{*}$ \\
\hline & p & .265 & .004 & .061 & .001 \\
\hline \multirow{2}{*}{ familial esteem } & I & .22 & .00 & .32 & .01 \\
\hline & $p$ & .059 & .992 & .641 & .903 \\
\hline \multirow{2}{*}{ Social esteem } & r & .03 & .09 & -.40 & .33 \\
\hline & $p$ & .770 & .788 & .741 & .804 \\
\hline \multirow{2}{*}{ School esteem } & I & $.25^{*}$ & $.68^{*}$ &. $.40^{\circ}$ & $57^{*}$ \\
\hline & $p$ & .033 & .002 & .045 & .0431 \\
\hline \multirow{2}{*}{ Global esteem } & r & .14 & .067 綵 & $.44^{*}$ & $.49^{*}$ \\
\hline & p & .189 & .008 & .03 & .021 \\
\hline
\end{tabular}

$\mathrm{R}^{2}$ : reajusted : 0.52 . $\mathrm{r}$ : coefficient de correlation de Bravais Pearson; p est la probabilité de signification $(\mathrm{p}<0.05)$

** : $\mathrm{p}<0.01$ la corrélation $\mathrm{r}$ est très significative à $99 \%$.

$*: \mathrm{p}<0.05$ la corrélation $\mathrm{r}$ est significative à $95 \%$.

The results in Table 2 show thatacademic self-esteem in both genders correlates with the levels of marks and ratings obtained during training. A result that correlates with physical self-esteem. Indeed, the higher the student's academic self-esteem, the higher the student's physical self-esteem.

On the other hand, the other dimensions of self-esteem (family and social) are not significantly impacted by the academic results obtained.

As a result, scores in the self-esteem domains vary significantly depending on the nature of the demands of the act to be done. It is in the family self-esteem score that students score the highest. Constraints and practical requirements during training do not negatively affect students' family self-esteem and therefore maintain a good self-worth shared with their family circle.

On the other side, it is in the academic self-esteem score that they achieved the lowest level, and this concerned especially those students who had modest academic results during the training period. The students targeted by the survey are therefore conditioned by initial representations of a desired "student athlete" prototype. The contrasting results in the different forms of physical practice led them to be confused and uncertain about their chances of adapting to this training.

\subsection{Variation in physical self-esteem between genders}

Table 3: Variation in scores in the areas of self-esteem and practical competence based on gender.

\begin{tabular}{|c|c|c|c|c|c|c|}
\hline Parameters & Gender & $\begin{array}{l}\text { Physical esteem } \\
\text { (Mean } \pm \text { sd) }\end{array}$ & $\begin{array}{l}\text { Familial esteem } \\
\text { (Mean } \pm \text { sd) }\end{array}$ & $\begin{array}{l}\text { Social esteem } \\
\text { (Mean } \pm \text { sd) }\end{array}$ & $\begin{array}{c}\text { School esteem } \\
\text { (Meant sd) }\end{array}$ & $\begin{array}{l}\text { Global self esteem } \\
\text { (Meant sd) }\end{array}$ \\
\hline \multirow{2}{*}{$\begin{array}{l}\text { Keep up with the } \\
\text { practice sessions }\end{array}$} & M & 34.857 .06 & $42.84 \quad 7.02$ & $35.15 \quad 8.76$ & 28.758 .93 & $72.96 \quad 13.56$ \\
\hline & F & 34.007 .06 & $44.21 * 6.60$ & 33.716 .01 & 26.369 .38 & $71.50 \quad 15.01$ \\
\hline \multirow{2}{*}{$\begin{array}{l}\text { Recover between } \\
\text { training sessions }\end{array}$} & M & $\begin{array}{lll}34.49 & 6.32\end{array}$ & 43.386 .27 & $\begin{array}{lll}34.05 \quad 9.26\end{array}$ & 27.498 .78 & $\begin{array}{lll}72.16 & 12.62\end{array}$ \\
\hline & & 34.887 .57 & $42.82 \quad 7.45$ & 35.567 .68 & 29.029 .17 & $73.14 \quad 14.60$ \\
\hline \multirow{2}{*}{$\begin{array}{l}\text { Animer un groupe } \\
\text { sur le terrain }\end{array}$} & M & 34.787 .26 & 42.297 .58 & $36.33 * 7.36$ & 28.648 .47 & $\begin{array}{lll}71.33 & 14.03\end{array}$ \\
\hline & F & 34.646 .86 & 43.886 .16 & 33.409 .18 & 28.079 .60 & $74.21^{*} \quad 13.39$ \\
\hline \multirow{2}{*}{$\begin{array}{l}\text { Respect the time } \\
\text { available engage in } \\
\text { practice }\end{array}$} & M & $34.32 \quad 6.12$ & $43.21 \quad 6.65$ & 34.129 .19 & 28.799 .22 & $73.84 \quad 13.50$ \\
\hline & F & $35.47 \quad 8.57$ & $42.77 \quad 7.56$ & $36.43 * 6.41$ & 27.578 .62 & $70.60 \quad 14.11$ \\
\hline \multirow{2}{*}{$\begin{array}{l}\text { Running in } \\
\text { Endurance }\end{array}$} & M & 34.846 .53 & $43.08 \quad 6.75$ & $36.22 * 7.71$ & 27.549 .12 & $71.36 \quad 13.68$ \\
\hline & $\mathrm{F}$ & 34.547 .74 & $43.03 \quad 7.29$ & 33.169 .00 & 29.498 .80 & $74.57^{*} \quad 13.75$ \\
\hline \multirow{2}{*}{$\begin{array}{l}\text { Support Strength } \\
\text { Exercises }\end{array}$} & M & 33.887 .00 & 43.216 .36 & 35.218 .35 & 27.948 .51 & $72.34 \quad 14.22$ \\
\hline & F & $37.68^{*} \quad 6.47$ & $42.53 \quad 8.88$ & 33.898 .60 & 29.8910 .63 & 74.1112 .00 \\
\hline \multirow{2}{*}{$\begin{array}{l}\text { Be accepted by } \\
\text { others in the game }\end{array}$} & M & 35.186 .76 & $43.82 * 6.24$ & $35.18 \quad 8.18$ & $29.63 * 8.72$ & $72.21 \quad 13.47$ \\
\hline & $F$ & $33.83 * 7.56$ & $41.60 \quad 8.02$ & $34.43 \quad 8.85$ & 25.979 .15 & $\begin{array}{lll}73.70 & 14.38\end{array}$ \\
\hline \multirow{2}{*}{$\begin{array}{l}\text { Progress in } \\
\text { learning techniques }\end{array}$} & M & 34.756 .77 & $43.25 \quad 6.66$ & $35.34 * 8.67$ & 28.648 .95 & $72.69 \quad 14.16$ \\
\hline & $\mathrm{F}$ & 34.617 .87 & $42.52 \quad 7.80$ & 33.747 .53 & 27.619 .24 & $72.83 \quad 12.74$ \\
\hline
\end{tabular}

*: significant variation $\mathrm{p}<0.05$.Comparison of group tests by Mann Whitney's nonparametric test.

Data are presented with mean and Standard deviation (sd).

For variations in the demands of physical practice, self-esteem scores are distributed across the different domains into averages and standard deviations. Gender is selected to express the heterogeneity or homogeneity of the responses obtained. Female students (F) have a tendency close to the representations of male students (M). (As expressed onTable 3)

As a result, scores in the self-esteem domains vary considerably based on the nature of the work to be performed. Students perform best in the area of family self-esteem. The constraints of practical demands during training do not negatively affect students' family self-esteem and therefore maintain a good selfesteem shared with their family circle. This applies to both genders.

On the other hand, it is in the academic self-esteem score that they have reached the lowest level, and this is especially true for students who have had modest academic results during the training period. The students targeted by the survey are therefore conditioned by the first representations of a desired "student-athlete" prototype.The contrasting results of the different specialities of physical practice led them to be confused and uncertain as to their chances of adapting to the requirements of this new training. 


\subsection{Variationof self-esteem scores and writing competencies between genders}

Table 4:Variation in scores in the areas of self-esteem and wrinting competences based on gender.

\begin{tabular}{|c|c|c|c|c|c|c|c|c|}
\hline Parametres & $\overline{\text { Gender }}$ & $\begin{array}{c}\text { Physical } \\
\text { esteem } \\
\text { (Meant sd) }\end{array}$ & $\begin{array}{c}\text { Familial esteem } \\
\text { (Mean } \pm \text { sd) }\end{array}$ & $\begin{array}{c}\text { Social } \\
\text { Esteem } \\
\text { (Meant sd) }\end{array}$ & $\begin{array}{c}\text { School } \\
\text { Esteem } \\
\text { (Meant sd) }\end{array}$ & & $\begin{array}{r}\text { Global } \\
\text { Esteem } \\
\text { (Mean } \pm \text { sd) }\end{array}$ & \\
\hline \multicolumn{9}{|l|}{ Oral requirements } \\
\hline \multirow{2}{*}{$\begin{array}{l}\text { Writing notes in a } \\
\text { course }\end{array}$} & M & 35.036 .91 & 41.897 .52 & 34.228 .57 & $28.05 \quad 10.14$ & 70.46 & & 13.68 \\
\hline & $\mathrm{F}$ & 34.487 .17 & $43.92 * 6.42$ & 35.448 .26 & 28.608 .13 & $74.40 * *$ & & 13.65 \\
\hline \multirow{2}{*}{$\begin{array}{l}\text { Use the draff for your } \\
\text { own reproduction }\end{array}$} & M & 34.407 .02 & $43.22 \quad 6.48$ & 35.237 .86 & 27.698 .74 & 72.60 & & 13.70 \\
\hline & $\mathrm{F}$ & 35.647 .16 & 42.598 .30 & 34.009 .87 & $30.36^{*} 9.60$ & 73.09 & & 14.10 \\
\hline \multirow{2}{*}{$\begin{array}{l}\text { Analyze successfully } \\
\text { the requirements of the } \\
\text { questions asked }\end{array}$} & M & 34.337 .08 & $44.00^{* *} 5.67$ & 35.218 .71 & 28.889 .31 & 72.26 & & 13.28 \\
\hline & F & 35.437 .00 & 41.278 .70 & 34.377 .80 & 27.408 .41 & 73.60 & & 14.72 \\
\hline \multirow{2}{*}{$\begin{array}{l}\text { Understand the work } \\
\text { expected }\end{array}$} & M & 34.977 .26 & $43.18 \quad 7.17$ & 35.198 .63 & $28.48 \quad 9.28$ & 73.00 & & 13.58 \\
\hline & $\mathrm{F}$ & 33.856 .29 & $42.65 \quad 6.27$ & 34.007 .56 & 28.008 .13 & 71.80 & & 14.49 \\
\hline \multirow{2}{*}{$\begin{array}{l}\text { Observe the writing } \\
\text { instructions }\end{array}$} & M & 34.547 .02 & 43.107 .25 & $35.39 * 8.06$ & 28.139 .25 & 72.79 & & 13.64 \\
\hline & $\mathrm{F}$ & 35.127 .18 & $42.96 \quad 6.29$ & 33.819 .13 & 28.928 .49 & 72.58 & & 14.19 \\
\hline \multirow{2}{*}{$\begin{array}{l}\text { Diversifying the } \\
\text { argumentative options } \\
\text { for a response }\end{array}$} & M & 34.877 .15 & 42.867 .38 & 34.998 .80 & 28.149 .02 & 72.72 & & 13.74 \\
\hline & F & 34.116 .73 & 43.834 .99 & 34.676 .66 & 29.229 .05 & 72.72 & & 14.03 \\
\hline \multirow{3}{*}{$\begin{array}{l}\text { Elaborate a synthesis or } \\
\text { a mental map }\end{array}$} & M & 34.756 .71 & $43.55 \quad 6.37$ & 35.207 .57 & $29.27 * 8.46$ & $73.98^{*}$ & & 13.46 \\
\hline & $\mathrm{F}$ & 34.657 .69 & 42.167 .89 & 34.429 .76 & 26.749 .80 & 70.45 & & 14.12 \\
\hline & M & 34.277 .25 & 42.297 .34 & $34.40 \quad 8.96$ & 28.529 .47 & 73.31 & & 13.62 \\
\hline \multirow{2}{*}{$\begin{array}{l}\text { Develop and Compose } \\
\text { Documentary Research }\end{array}$} & $\mathrm{F}$ & & & & & & & \\
\hline & & 35.376 .73 & $4.20 * 6.23$ & 35.697 .46 & 28.148 .36 & 71.86 & & 14.02 \\
\hline
\end{tabular}

(*) Les différences significatives entre les deux sexes en référence à l'indice $\mathrm{p}<0.05$.

Data presented with (Mean and \pm standard deviation)

For difficulties in writing requirements, the results show that disparities are also significant between the different domains of self-esteem. However, there is stability in academic self-esteem, which remains the lowest performing domain compared to the other selfesteem domains. The demands on students' writing skills are more difficult and the constraints are more accentuated than those encountered in practical competencies are.

Females once again, scored higher than males in terms of their ability to adequately meet the requirements of certain writing skills.

This superiority of scores in some writing skills requirements correlated with some dimensions of selfesteem. Indeed, the superiority of scores in writing skills requirements recorded among females correlated with their scores in school and family self-esteem (Table 4).

On the other hand, the requirements of the new training expectations for university students (Develop and Compose Documentary Research, Observe the writing instructions and elaborate a synthesis or a mental map) are perfectly mastered by the male gender, push their family, and school self-esteem scores further than those of the female gender. This is another expression of the inter-gender variation. This is what we can see at this stage of the justification of the results.

In the final anachronistic (Table 4), we therefore found eight significant variations between boys and girls. They concerned school, family, and global selfesteem, and this when the perception of mastery of the requirements of writing skill is high.

\subsection{Variation of self-esteem scores and oral competencies between genders}

Table 5: Areas of self-esteem and requirements of oral competencies.

\begin{tabular}{|c|c|c|c|c|c|c|}
\hline $\begin{array}{l}\text { Parametres } \\
\text { Oral Requirements }\end{array}$ & Gender & $\begin{array}{l}\text { Physical } \\
\text { Esteem } \\
\text { (Meant sd) }\end{array}$ & $\begin{array}{c}\text { Familial } \\
\text { Esteem } \\
\text { (Meant sd) }\end{array}$ & $\begin{array}{c}\text { Social } \\
\text { Esteem } \\
\text { (Meantsd) }\end{array}$ & $\begin{array}{c}\text { School } \\
\text { Esteem } \\
\text { (Meantsd) }\end{array}$ & $\begin{array}{c}\text { Global } \\
\text { Esteem } \\
\text { (Meant sd) }\end{array}$ \\
\hline \multirow{2}{*}{$\begin{array}{l}\text { Build a good oral } \\
\text { discussion }\end{array}$} & M & 34.637 .23 & 42.717 .83 & 33.739 .17 & 29.448 .71 & $72.85 \quad 14.47$ \\
\hline & F & $34.78 \quad 6.92$ & $43.37 \quad 6.11$ & $35.98 * 7.53$ & $27.41 \quad 9.21$ & $72.61 \quad 13.18$ \\
\hline \multirow{2}{*}{$\begin{array}{l}\text { Speaking in front of the } \\
\text { audience }\end{array}$} & M & $34.87 \quad 6.70$ & $43.36 \quad 6.13$ & $34.43 \quad 9.23$ & $30.00 * 8.92$ & $72.17 \quad 13.42$ \\
\hline & $\mathrm{F}$ & 34.537 .48 & 42.707 .85 & 35.507 .31 & 26.458 .79 & $73.38 \quad 14.21$ \\
\hline \multirow{2}{*}{$\begin{array}{l}\text { Communicating ideas to } \\
\text { the teacher }\end{array}$} & M & $34.54 \quad 6.87$ & $43.73 \quad 6.08$ & 35.887 .87 & 28.529 .66 & $71.29 \quad 14.61$ \\
\hline & F & $34.97 \quad 7.35$ & $42.06 \quad 8.04$ & 33.498 .98 & $28.14 \quad 8.02$ & $74.86 * 12.17$ \\
\hline \multirow{2}{*}{$\begin{array}{l}\text { Criticize and impose } \\
\text { yourself on the ideas put } \\
\text { by others. }\end{array}$} & M & $35.16 * 6.94$ & $42.75 \quad 7.15$ & 33.598 .93 & 28.358 .88 & $73.00 \quad 13.16$ \\
\hline & F & $33.54 \quad 7.29$ & $43.88 \quad 6.41$ & $38.42 * 5.42$ & $28.42 \quad 9.47$ & $72.00 \quad 15.38$ \\
\hline \multirow{2}{*}{$\begin{array}{l}\text { Listen and concentrate in } \\
\text { classroom }\end{array}$} & M & 33.817 .39 & $44.02 * 6.14$ & $35.48 \quad 7.76$ & 28.338 .54 & $72.38 \quad 13.15$ \\
\hline & F & $35.82 * 6.48$ & $41.87 * 7.73$ & $34.23 \quad 9.12$ & 28.419 .62 & $73.15 \quad 14.56$ \\
\hline \multirow{2}{*}{$\begin{array}{l}\text { Easy exchange with the } \\
\text { audience }\end{array}$} & M & 34.317 .04 & $42.94 \quad 7.29$ & $35.13 \quad 8.63$ & $28.02 \quad 9.36$ & $73.60 * 12.57$ \\
\hline & F & 35.217 .08 & $43.21 \quad 6.58$ & $34.67 \quad 8.15$ & 28.798 .61 & $71.64 \quad 15.12$ \\
\hline
\end{tabular}

(*) Les différences significatives entre les deux sexes en référence à 1 'indice $\mathrm{p}<0.05$.

Data are presented with mean and standard deviation (sd).

Once again, we found variations between the two genders on the requirements for oral proficiency. They concern the scores achieved by girls on two dimensions of self-esteem: social and academic selfesteem. Females scored higher than males in the latter dimensions of self-esteem (M 33.73 Mean, 9.17 sd / F 35.98* Mean, $7.53 \mathrm{sd})$. A perception of girls expressed by crossing it with their ability to: "Build a good oral discussion, speaking in front of the audience" as expressed in (Table 5).

Girls also score well compared to boys on the dimension of social self-esteem (M 33.59 Mean, 8.93 sd / F 38.42* Mean, 5.42 sd). This is expressed by increasing this dimension of social self-esteem with their ability to: "Criticize and impose yourself on the ideas put by others". 
On the other hand, boys scored higher and showed significant variations in their overall self-esteem. They also express high scores in their ability to: "interact appropriately with the audience" (Table 5).

For both genders, the results reveals similarities between oral and written scores. Students in their judgments about self-efficacy during this training period confirm the links between the indicators of "core training skills".

\section{ANALYSE}

We recall that the objective of the study is to verify the presence or absence of correlational links between the variables: self-esteem and academic results obtained by students of both genders. On the other hand, to verify the variations of these links based on gender. This in order to optimize the constraints of the beginning of the training and to accompany the specific progress of both genders.

Therefore, guarantee the success of all students in their training by taking into consideration their particular needs.

The analysis of the data relating to the crossing of the variables taken: "self-esteem, academic results and their variations based on gender" shows that the total number of experienced students confirms a very satisfactory self-esteem. Especially in the academic, family and social areas for the female gender. Good results and scores of the latter in the global self-esteem will have to favour their success in the next stages of their training.

Indeed, for practical requirements, the female gender shows higher scores than the male gender. This concerns their ability to withstand high intensity efforts and long allene physical work. Furthermore, in this overall skill of practice training, boys show higher scores than girls in the requirements for physical endurance efforts and easy acceptance by others ingroup work.

In other parts for the written requirements, the scores again show high variations in the female gender and consequently show a superiority over the boys. These variations are significant in overall, family and school self-esteem (Table 4).

Finally, for overall oral proficiency, the female gender shows distinctively high scores in speaking in front of others with good overall self-esteem. An advantageous predisposition for further training for girls compared to boys. In terms of listening skills and concentration in class, boys (Table 5) score more favourably than girls, and this has corollary tendencies with their social self-esteem, which also increases significantly.

As a result, it turns out that the male gender is mainly concerned with his social self-image to please others more than his interest in furthering his current education.

Therefore, the disparities in scores in the cited requirements presupposes the design of programs adapted to the efforts and needs according to the resources of each gender. Thus, no longer consider the feminine gender based on an allegedly masculine one only. It is therefore necessary to start from a nonstereotypical vision and without the only image of the "masculine" profile to be formed. Girls will therefore have the opportunity to perfect their skills by gradually transforming themselves at their own pace. Boys also adopt their work rhythms according to their tastes and intensities in the different training requirements.

\section{DISCUSSION}

The variations verified in the different areas of selfesteem between genders during this training show that the female gender is far from certain received ideas about the fragility of self-esteem in them. Through the results obtained, they displayed a good self-image compared to their fellow trainees compared to boys. In fact, they feel they are appreciated in their university activities and in their family esteem. This will enable them to follow up on their requirements and consequently to adapt well to the training. Oral skills requirements are accessible and significantly more manageable for females than for males. As a result, they will be the driving force behind the motivation of the training groups throughout the training. The mixed interaction during the training between the two genders will generate an interest from both genders for more collective production and efficiency in the different stages of the training.

The same applies to the written competence requirements. Girls scored significantly better than boys did. Variations in the different areas of selfesteem, therefore, depend on gender according to the results obtained. In writing job requirements, the female gender surpassed the male gender, which consequently also raised their scores in academic and family self-esteem.Disparities between girls are also significant, with intra-gender standard deviations ranging from [13.18 to 15.38] (Table 5). For boys, the results also show a heterogeneity in scores, but less than for girls [12.57 to 14.61] (Table 5).

As a result, a minority of girls are considered having difficulties in training, far from a good majority who seem to be on the road to a good success. For boys the intra-gender disparity is not significant. It can therefore be deduced from this that, despite the good collective scores for girls in terms of overall selfesteem and academic achievement, there are still a few cases of failure. It is this minority, which also interests us in order to accompany them in this difficulty by allowing them to keep pace with the others in the best conditions.

On the other hand, on the results of (Table 2), we can see as a reminder that academic (university) selfesteem of both sexes correlates with the levels of marks and evaluations obtained during training. These results also correlate significantly with physical selfesteem. This reveals the peculiarity of this training, which is also based on physical resources. In fact, the higher the student's academic self-esteem, the higher the student's physical self-esteem. 
On the other hand, the other dimensions of self-esteem (family and social) are not significantly impacted by the academic (university) results obtained. Constraints and practical demands during the course of study do not negatively affect students' family self-esteem and therefore maintain a good self-esteem shared with their family circle. This good factor often helps new students in university education. Petre, C., Simion, L. \&Marica, M. (2017).

The students targeted by the survey are therefore conditioned by the first representations of a desired "student-athlete" prototype. The contrasting results of the different forms of physical practice led them to be confused and uncertain as to their chances of adapting to this training. The training situation in this field presents difficulties to be further optimised by taking into account the three ergonomic variables: subject, environment and activity to be performed. Students must follow targeted support programmes based on constraints. To do this, diagnostic devices towards the end of the first semester are strongly advised.

\section{SUGGESTIONS}

In the light of the verification of the experimentalfacts of thisstudy and by reinvesting some of the writings identified at its beginning, we suggest that, every person achieves high self-esteem when they achieve successes that are equal to or greater than their ambitions.

This occurs regardless of gender, Oxman, A. (2018).Therefore, in order for a student to experience success and support it, itisvery important thatthey are offered realistic goals and are confident that they are capable of achieving them. These realistic and attainable goals become protective factors for selfesteem.

In another perspective, no one canactualize and develop by accumulating only failures. In this study, male students perceive themselves to be in relative difficulty compared to female students. It is highly recommendable to support those who are experiencing difficulties with optimised measures in the context of sub-programmes parallel to the usual training. Without forgetting, however, that a personcandraw a lesson or a lesson from each failure in order to reassurehimself or herselfsomewhat about his or herpersonal value. It isthereforeobvious to considerthat self-esteemis not acquired once and for all, itneeds to be constantly nourished, in particular by new successes in the various training exercises. This allows us to stipulate that the reassuring situation in "self-esteem" of the majority of girls must be monitored so that it lasts longer throughout the training course.

Finally, supporting students to developtheir feelings of competence regardless of gender presupposes making specific comparisons to identify particular gender gaps. Especially in a training thatrequiresmotor performance and commitment to physical preparation. A field of biological disparities... between genders of ten unfavourable to girls. It willtherefore have to be carefully considered when designing programmes for this mixed and very heterogeneous population.

We have seenthattendencies to adequately support certain life skills efforts are mainlyrelated to physical self-esteem. This is an aspect that varies greatly between genders depending on our study results. For this reason, it is also highly recommendable to effectively support students' self-esteem in itsdisparities and to prescribe a climate of confidence and securityduring the early stages of their vocational training. Self-esteem is therefore not monolithic, but isbuilt up through positive experiences in different situations. Thus, this "self-esteem" does not dependexclusively on the student, but also on the types of teaching arrangements put in place by the trainers and the statusattributed to gender issues in the host training institution.

\section{CONCLUSION}

Identifying and understanding the relationship between the students' self-state and their variations based on the two genders is the main objective of this work. Thus, this prior knowledge of gender disparity has been expressed in the results obtained in this work. The summary tables have shown that the selfstates are significantly variable according to the gender questioned.

As a result, the girls revealed a good predisposition to the challenges of single and coeducational training.

On the other hand, it can be said that this work can be a good precursor to better optimisation of interventions during this training programme for a mixed population.

The extension of this work on the perception of competence and self-esteem in both sexes will converge on the triggering of motivation and improve the powers of action during training. The disparity in perception between the two sexes has an impact on the results of the degree of adaptation of both sexes to the targeted learning. The female gender has better results for successful adaptation to learning in the near future. Finally, we are convinced with CanisiusKamanzi, P. Lessard, C. \& Tardif, M. (2019) that the close followup of our "future teacher" students also gives us academic value and shapes a positive belief in our training activities. This monitoring will also be relevant insofar as it also makes it possible to effectively support the students' self-image in their disparities and to prescribe a climate of mutual trust.

\section{REFERENCES}

[1].Aebli, H. (2019). PsychologicalDidactics. Application à la didactique de la psychologie de Jean Piaget, Perspectives interdisciplinaires sur le travail et la santé [Online], http://journals.openedition.org/pistes/6268 ; DOI : $10.4000 /$ tracks. 
[2].Bandura, A. (2005). "Self-Efficacy Beliefs of Adolescents", 307-337, by Information. Age Publishing.

[3].Barbot, B., Safont-Mottay. C. andOubrayrieRoussel. N. (2019). Multidimensional Self-Esteem Scale (EMES-16): Psychometric evaluation of a domain-specific measure of self-esteem for francophone adolescents. The International Journal of Behavioral Development (IJBD). Volume: 43, $\mathrm{N}^{\circ}$ 5, pages: $436-446$.

[4].Bariaud, F. (2006). The Self-perception profile for adolescents (SPPA) by S. Harter; Educational and vocational guidance, $35 / 2$.

[5].Canisius Kamanzi, P. Lessard, C. and Maurice Tardif, M. (2019). Job satisfaction of Canadian teachers; Canadian Journal of Education / 42:4. Canadian Society for the Study of Education.

[6].Cohen-Scali, V. Zein, R. Vignoli, E. and Lallemand, N. (2019). The risk of dropping out of school of Lebanese schoolchildren. In Psychological Practices Volume 25, Issue 3, September 2019; 329-347p.

[7].Delignières, D. (2007). The fractal dynamics of self-esteem: a statistical validation. Science \&Motricity, 60, 69-73.

[8].Duclos, G. (2004). Self-esteem, a passport to life. Éditions de l'Hôpital Sainte-Justine, Montreal.

[9].Famose, J. P. andBertsch, J. (2009). Self-esteem: an educational controversy. Presses universitaires de France.

[10]. Fiassa, D. and Nader-Grosbois. N. (2010). From Perception to Self-Esteem : Concept, Assessment and Intervention; Editions De Boeck Supérieur ; pages 77, 78 .

[11]. Guerin, S. andTatlow-Golden, M. (2018). How valid are measures of children's selfconcept/self-esteem? "Factors and content validity in three widely used scales". Journal of Youth and Adolescence, 12, 1507-1528.

[12]. Harter, S. (1993). "Causes and consequences of low self-esteem in children and adolescents". In Baumeister, R. (Ed.). Self-esteem: The puzzle of low self-regard. New York Plenum, 1993, pp. 87111.

[13]. Hepper, E.G., Gramzow, R.H, andSedikides, C. (2010). Individual differences in selfenhancement and self-protection strategies: An integrative analysis. Journal of Personality, 78, 781-814.

[14]. Oxman, A. (2018). The relationshipbetween social media, self-objectification and self-esteem in youngadultwomen. In ; The sciences and Engineering, $\mathrm{N}^{\circ} 79$

[15]. Petre, C., Simion, L. and Marica, M. (2017). The family culture of schoolfailure.Pensée plurielle, 46(3), 19-31. doi:10.3917/pp.046.0019

[16]. Roux-Perez, T. (2006). Representations of the teaching profession and relationship to training among STAPS students: "a professional identity in construction", Staps, No. 73, pages 57-69.

[17]. Steffen, Mand Coll. The RevisedScale for Caregiving Self-Efficacy : Reliability and
ValidityStudies, The Journals of Gerontology: Series B, Volume 57, Issue 1, 1 Janvier 2002, Pages P74 https://doi.org/10.1093/geronb/57.1.P74

[18]. Virat, M. (2014). Emotional dimension of the teacher-student relationship: effect on the psychosocial adjustment of adolescents (motivations, empathy, school adjustment and violence) and the determining role of teacher's compassionate love. Université Paul Valéry Montpellier III. French. FFNNT: 2014MON30048ff.

[19]. Zedda, M., Thibodeau, S., and Lefebvre, S. (2018). Self-esteem and sense of social efficacy: "personal characteristics related to students'academic performance". Paper presented at Congress of the Quebec Society for Research in Psychology (SQRP), Québec, Canada. 